\title{
イヌの舌乳頭への放射線障害に関する実験的研究
}

\author{
九州菌科大学口腔解剖学第 2 講座（指導：嶋村昭辰教授） \\ 九州歯科大学备科放射線学講座 (指導：大庭 健教授)
}

富山元 也

昭和61年10月23日受付

\section{An Experimental Study on Radiation Hazard to Lingual Papillae of Dogs Motoya Tomiyama}

\author{
Second Department of Oral Anatomy (Director: Prof. Akitatsu Shimamura) \\ Department of Dental Radiology (Director: Prof. Takeshi Ohba) \\ Kyushu Dental College, Kitakyushu 803 Japan
}

Disturbance of the sense of taste is known to be caused by radiation therapy for tumors in the head and neck region. For the purpose of investigation of changes of the lingual papillae pathohistologically, $\mathrm{X}$-ray irradiation to the lingual dorsal membrane of the tongue was experimented and light microscopic and scanning electron microscopic observations were made. Nineteen young dogs, $3 \sim 5$ months old, were used for this experiment. Single dose of 1,000 was given in three irradiations at intervals of three days. Observations were made on the 1st, 3rd, 5th, 9th, 15th, 35th, and 60th days.

The main findings were as follows.

1. The dogs became slow in motion, lost appetite, and left a third of their feed beginning on the 5 th day after irradiation. From the 8 th to 9 th days, eye mucus and secretion from the eyes increased and appearance of weakness increased. Beginning on the 15th day, signs of recovery were observed.

2. The cases on the 5th day showed marked degeneration of yellowish-brown color of the lingual mucous membrane in the region closest to the irradiation tube.

3. Microscopically, the degenerated region was coincident with the region of erosion formation in which neither the lingual papillae nor epithelial layers were observed. Lamina propria of the mucous membrane where infiltration of inflammatory cells was marked was exposed directly.

4. Scanning electron microscopic observation of this erosion region showed a mixed finding of innumerable inflammatory cell group that migrated to the surface of the lamina propria and debris of the epithelial layer.

5. In the lamina propria of the mucous membrane of this region, connective tissue fibers were disorderly arranged and most blood vessels were congested and expanded. Muscular fiber groups extending to this layer were atrophied and striated structures 
were unclear.

6. The filiform and fungiform papillae in the ordinary mucous membrane neighboring to the degenerated one maintained their forms. However, erosion in part of the epithelial layer and edema in places including the lamina propria were seen. Scannig electron microscopically, both papillae changed some in morphology and their surfaces were rough, and countless microorganism and parasite-like structures aggregated together densely. The taste buds of fungiform papillae decreased in number, and showed atrophy, decrease, and vacuolar degeneration of their cells (light or sustentacular cells).

7. In the cases on the 5th day and those on the 15th day, the discolored region of mucous membrane was considerably limited beginning with the cases on the 9th day. In the cases on the 15 th day, limitation was brought about by restoration of epithelium. Inflammation of adjacent healthy colored region was slight.

8. The shorter the interval after irradiation, the lighter was disturbanced. In the cases of one day after irradiation, especially, any region appeared about the same as that of controls.

9. As epithelium of the mucous membrane recovered and prolifered in the cases on the 15th day and thereafter, the number of taste buds and of taste bud cells was restored. However, atrophy of cells still continued and cell arrangements were irregular. Even in the cases on the 35th day after irradiation infiltration of inflammatory cells was seen in some taste buds and complete restoration to the normal image was seen only after 60 days.

Key words : $X$-ray irradiation/Lingual papillae/Dog/Pathohistology /SEM

\section{緒 言}

頭頸部領域の腫煬に対する放射線照射によって，味覚 に異常障害を苾起することがよく知られている．放射線 治療を受けた患者についての味覚障害の程度や，その回 復に要する日数などを調べた研究報告はあるが1ー6, 病 理組織学的な立場から舌粘膜, とくに味筧乳頭ならびに 味菁にどのような形態学的変化が生じるかについての検 索はあまりなされていない，蹦床例における病理組織学 的報告は, 著者が胩椫しえた範囲では富田ら（1981）》 による扇桃癌（6.000 R 照射，56才男性）例のみの上う である、彼らによると，有郭乳頭には味蕾は全く垫めら れなかったと具体的に述べている。一方，動物実験によ る舌乳頭または味覚乳頭についての観察も比較的数が少 ない. マゥスについては Conger ら $(1969)^{8)}$, Schaupp ら (1972) ${ }^{3)}$, 太田 $(1973)^{91}$ の報告があり, ウシに ついては Schatzman ら $(1982)^{102}$, 魚類については Ghoneum ら $(1983)^{11)}$ な゙の報告があげられる. 彼ら
の報告の中で，ほぼ共通する所見として，味蕾の数の減 少, 味蕾紐胞の減少, 萎縮, 空胞変性などが指摘されて いる.乙れらの変化はすべて味覚器官の直接的変化であ って, てれらの変化が起る以前の味覚乳頭を含めた舌粘 膜全体としてのの病理組織学的な変化にも目を向ける必 要があると考える。

本研究では, 比較的少量のX線照射による影響に関す る文献的データを追試しつつ, 舌粘膜面の一般的病理学 的変化のなかでの味覚乳頭とその味蕾の変化がどのよう に把握されるかを検索した。実験動物には中動物として の幼大を用い, 肉眼的, 光顕的および走查電子顕微鏡的 (SEM) に観察した。 それによって, 先人の業績に若干 の追加し得る知見を得るととができたので，その詳細を 報告する。

\section{実験動物と方法}

実験動物としては, 生後 3 カ月から 5 カ月前後の雑種 幼犬を用いた，動物飼育室の犬舎にて一定期間馴れさせ 
てから実験に供した。それに要した幼犬は全部で19頭 で，照射後の経過 日数 1 日目，3日目，5 日目，9日 目，15日目，35日目を主に観察対象とした。コントロー ルには教空所蔵の標本を利用した．X線照射は九州歯科 大学歯科放射線学教室に設置されている高電圧深部治療 装置（皂津製信愛号）にて行った，管電压：200 kVp， 管電流 $20 \mathrm{~mA}$, Filter : $0.5 \mathrm{~mm} \mathrm{Cu}+1 \mathrm{~mm} \mathrm{Al}$, 焦点.

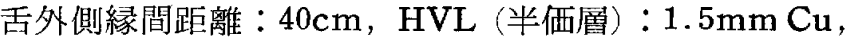
照射野： $4 \mathrm{~cm} \phi$ の条件下で $1,000 \mathrm{R} /$ 回/日として，3日 間隔で総線量 $3,000 \mathrm{R}$ を照射した，線墘測定は実験の都 度 Ionex 線量計で測定し，ほぼ毎分 $100 \mathrm{R}$ を確認した。

照射方法はンムノペンチル静脈注射で榞酔した動物を 側卧位に固定し，舌体中央部（左側下顎第 2 乳臼菌部に 相当）を中心に前記条件にて照射した（Fig．1）

観察方法

肉服的観察：照射前に訋犬の外観上の健康状態が正 常であることを確認し，さらに前記の方法で麻酔した後 で，舌をはじめとする口腔内諸組織を観察した，該当す る曰腔周辺の皮膚については観察の対象から除外した。

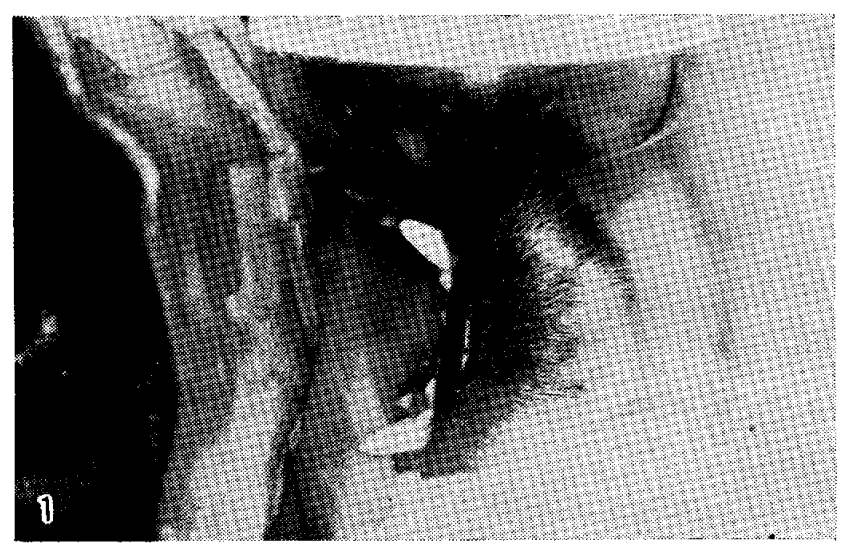

Fig. 1 幼犬頭部の固定と X 線照射

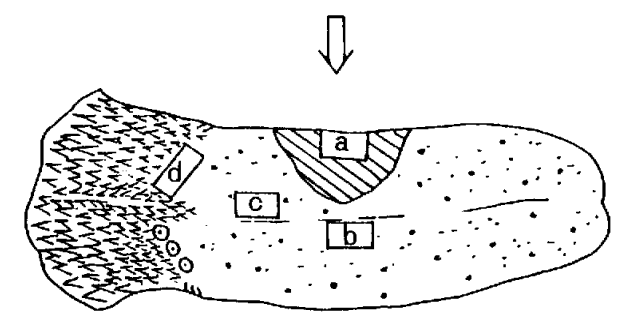

Fig. 2 幼犬舌背面の模式図

$\mathrm{a} \sim \mathrm{d}$ 部の粘膜を摘出して比較钼察し た。 a 部の斜線はX線照射後 9 日目に 現われた粘膜の变色領域を示す. 矢印 はX線の照射方向を指す。
なお，曰腔内組織粘膜の反応については楊 $(1981)^{12)}$ の 成䋶資料を参考にした。

光学顕微鏡的観察用：模式図 (Fig. 2) に示す 4 力所 ( $\mathrm{a}, \mathrm{b}, \mathrm{c}, \mathrm{d})$ からそれぞれ舌粘膜片（約 4 $\mathrm{mm}^{2}$ ) を摘出して切片標本を作製した，a 部位は照射 筒に最も近接する領域であるから障害を最も強くうける ところである，a部を含めた斜線領域は照射後 9 日例に て最も顕著に現れた粘膜変色域を示す。bとc 部位は, $\mathrm{a}$ 部位に隣接するとてろとして選んだ。 $\mathrm{d}$ 部位は，もう 一つの味覚乳頭として存在する有郭乳頭部を選んだ.

舌粘膜の試料摘出は肉眼的および実体顕微鏡的観察を 十分に行った後に行い, 直ちに Bouin 固定液に浸漬固 定した．固定後は，法に従ってパラフィン包埋， $4 \sim 6$ $\mu \mathrm{m}$ の切片調整, hematoxylin · eosin や Azan · Mallory 染色を施して鏡見した。

走查電子顕微鏡的観察用： $\mathrm{X}$ 線照射障害の最も強く 現われた照射後 9 日例の $a \sim c$ 部位のみを対象とした. 舌粘膜表面の微細構造を観察するため, 試料採取後值ち に Karnovsky（1965） ${ }^{13}$ 液にて 2 時間浸漬固定した. 次いで，0.1Mリン酸緩衝液で数回洗浄してから $1 \%$ 四 酸化オスミウムで 90 分間の後固定を行った. その後, エ タ,一ル脱水, 酢酸イソアミルによる置換, 臨界点乾 燥, 白金・パラシウムによるコーティングを経て JSM T-300走査型電顕（SEM）にて観察した。

所見

1. 照射後の飼育観察

1) 1 回目と 2 回日の照射 (2000R) 後のイヌの日常 状態はほとんど変化はない，食欲良好(飼料：イ邓用固 型ビスケット), 元気よく走り回り, 排泆状沉もよい.

2) 3 回目の照射後になって, 挙動に変化が現われ る。その主なものは次の通りである。

a . 照射終了翌日から犬舎の外に出るのを泘がる．食 欲に変化はない。

b. 照射後 3 日目になって, 日常の元気さがなくな り，すべての動作が緩慢である．食欲も不振で，軟かい ものを好食する。

c. 照射後 5 日目にて食欲の減退が著しく，飼料を1/3 ほど残すようになる。動作もより緩慢，目ヤニが出る。

d. 照射 9 日目にて，目ヤ二，流涙が多くなる。飼料 の残しも多く，衰弱感著しく，いかにも重篤症状感を呈 す。排便がない。

e. 照射後10日以降になって重篤症状から徐々に脱し て回復の徴候を見せる．照射15日〜20日にて少し食欲も 
出て，動きもよくなってくる，

\section{2. 非照射舌の肉眼的観察}

イヌの舌は全般的に細長く, 前方約 45 の舌背を左右対 称的に分ける舌正中溝を有するが，前方約 $1 / 2$ まで顕著 で, それより後方は濑次不明瞭になっている，七トにて 観察される舌分界溝や舌盲乳は認められない。

系状乳頭は舌尖からほぼ舌背全面にわたって分布する が, 舌根部のものがより発達していて糸状よりも円錐状 が相応しい外観を呈する．苜状乳頭はヒトをはじめとす る他の動物とと同じく舌体部に散在性に分布する，有郭 乳頭は舌後方約 $1 / 5$ 扨に逆 $\mathrm{V}$ 字形を描くように $4 \sim 7$ コ配 列している. 葉状乳頭は舌根部外側縁にして, 口蓋舌弓 の前縁に存在する。

3. 非照射舌の光顕的および走査電顕的観察

有郭乳頭列より前方の舌背全面には，ほほ一定した形 と大きさの糸状乳頭が分布するが，その形態像はFigs. 8-A，B，Cに示すように，一次，二次拈よび三次乳 頭よりなる，その中の一次乳頭が最も大きくて，本乳頭 の主体をなし, 比較的小さな 2 本の二次乳頭とともに三 尖状の外観をなす，乳頭の尖端は大体舌根側に向けてい る. 三次乳頭はより小さな乳頭にして，一次と二次の前 方基底部に一定間隔在保って 4 本以上植立している。乙 れらの乳頭の表面は至って平滑で, 個々の細胞境界が識 別される．上皮層表面の一部が剥離しかけているところ も散見される。

乳頭表面を被覆する重圆扁平上皮層は成犬に比べる と，かなり薄い．とくに表睥の角化層と下層の有棘細胞 風の厚さに相異が認められる. 染色反忍による角化度を みても，幼犬の場合はかなり弱く，そのほとんどは錯角 化である。また，乳頭の芯に相当する乳頭固有層の線維 性結合組織の配列も成犬に比べると，幾分粗雑な配列を なしている。

茸状乳頭は前記の糸状乳頭間のみならず，舌根部の円 錐乳頭間にも散在する.本乳頭の大部分の表面は，ヒト をはじめとする他動物と同じく，半円球状を呈するが， 部分的に，とくに舌尖部のものは多少その外形を歪めて いる. 大きさは，舌の後方のものほど大きい傾向にある (最大径 $250 \sim 350 \mu \mathrm{m}$ ) .

本乳頭は僅かに角化した重圈扁平上皮にて被覆され， その背面上皮中には大抵味蕾が分布する. Brouwer ら (1978） ${ }^{14)}$ 亿よって試みられた味孔染色法（1\% Ponceau S) を施すと，平坦な背面上皮面に多くて 8 コの 味孔を認めることができる，切片上においてる，同心゙数 の味蕾の分布を観察するととができる。
有郭乳頭はヒトにみられるような, 舌正中位のものは なく, 片側に $2 \sim 3$ コ又は $2 \sim 4$ ב存在する. 乳頭の周 りには比較的深い溝を介して, かなり不規則な形の輪郭 部があり, 部分的に冈錐乳頭に移行する乳頭もみられ る. 乳頭の背面は比較的平坦であるが，その中央辺に一 コのくぼみ (depression) を有することがある。このく ぼみの深さは乳頭によって異なる．乳頭と輪郭部の溝面 上皮層中には沢山の味蕾が分布する，溝底よりほどその 密度が高い。味蕾は乳頭背面のくぼみの上皮中, ときに は他の背面上皮中にも観察されることがある. 乳頭溝底 には, 他動物と同じように, 漿液腺 (エブネル腺) の導 管が多数開口する。

4. 照射舌の肉眼的および光顕的観察 照射後 1 日例：

全般的にはコントロールとほとんど変らない，僅かに 粘膜面が粗造感を呈する。

$\mathrm{a}$ 部位：糸状，咠状の両乳頭の基本的形態はコント ロールと変らないように見えるが，細かく観察してみる と系状乳頭の上皮の各首に変化が認められる.つまり, 角化層が厚くなり，顆粒圓における顆粒の分布密度が高 く，有棘細胞風が少しばかり狭くなっている。

茸状乳頭では，背面にも薄い角化首を認められる以外 は正常とほとんど変らない，背面上皮首に分布する味蕾 細胞に僅かな萎縮傾向がみられるが, 味蕾の数, 大きさ には変化はみられない（Fig．3-A)。

$\mathrm{b}$ 部位： 系状乳頭は $\mathrm{a}$ 部位と変らない状態を示す が，咠状乳頭の外観に異常が認められる。いわゆる茸状 を旺する外形の乳頭が見当らない，Fig. 3-Bに示す ように，乳頭の側方遊離部の発育がなく，乳頭全体が沈 下してしまって，背面部だけが遊離面に僅かに突出する 形状をなす．外観的にはX線の照射障害というょりも， むしろ発育不全に近い状況を呈するように見える。も ろん背面上皮層に分布する味蕾の細胞はすべて萎縮傾向 を示し，核も濃縮している。味蕾の数的分布は $3 \sim 6$ ב で, 正常数と変らない。

$\mathrm{c}$ 部位： $\mathrm{b}$ 部位と大差ない

$\mathrm{d}$ 部位：有郭乳頭の外観扝よび上皮層の構成は正常 とほとんど変らない，茸状乳頭と同じょうに，背面上皮 層の中にも数コの味蕾が観察される。溝面上皮風に分布 する味蕾を含めて，味蕾細胞のほとんどは萎縮傾向を 示す．乳頭固有層における血管，神経の分布は比較的豊 富である．乳頭下固有風の血管はやや充血傾向を示す (Fig. $3-\mathrm{c}$ ).

照射後 3 日例： 

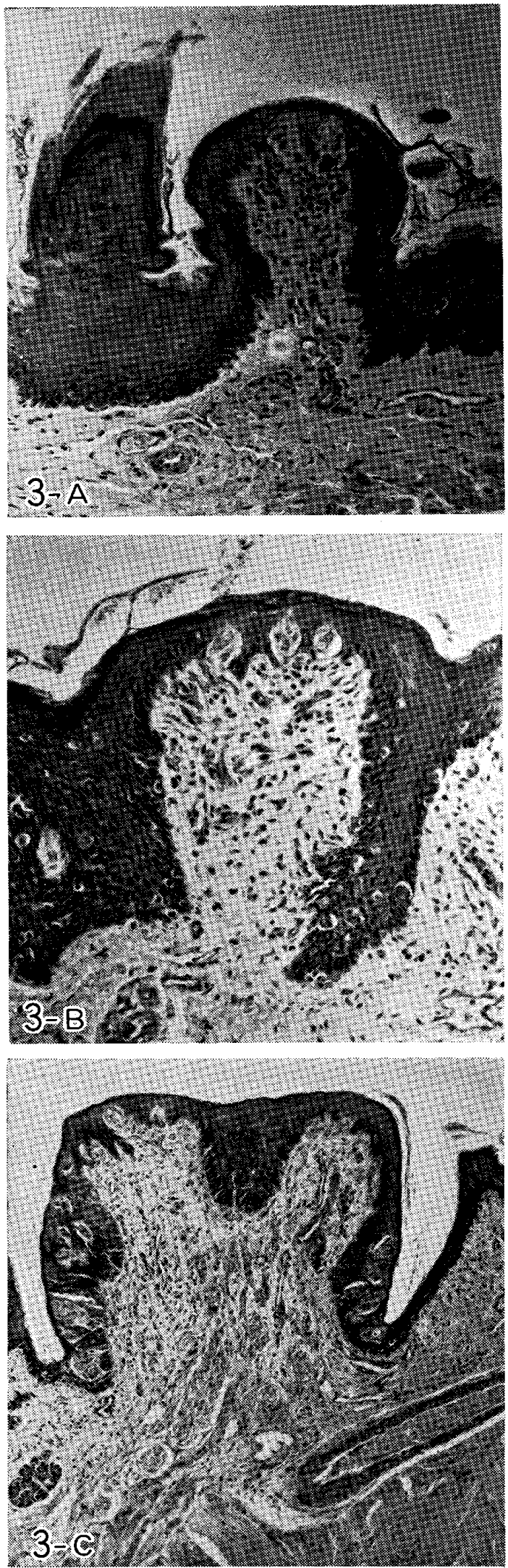

Figs. 3 照射後 1 日例の組織像

A： $\mathrm{a}$ 部位の糸状乳頭と茸状乳頭 $5 \times 20$

$B ： b$ 部位の茸状乳頭 $5 \times 20$

$\mathrm{C} ： \mathrm{~d}$ 部位の有郭乳頭 $5 \times 20$
粘膜面全体の色調は 1 日例と同じく，ほとんど変らな いが，粘膜面の粗造感はより一層強い。

$\mathbf{a}$ 部位： 糸状乳頭上皮層の半分ほどあるいは部位に よってはそれ以上にわたっての角化層剝離が顕著であ る. 残こ有棘細胞層でも細胞核の空胞化, 細胞間隙の増 大, 遊走細胞の浸潤が多く観察される。一部の系状乳頭 では，その形態のほとんどが崩壊しているものも見られ る.

茸状乳頭は糸状乳頭に比べると，その形態の保守は強 く，変性上皮層の中に漸く外観を保って存在する味蕾 を認めることができる。もちろん，味蕾紐胞のほとんど は萎縮変形し，細胞の種類の識別はほとんどできない
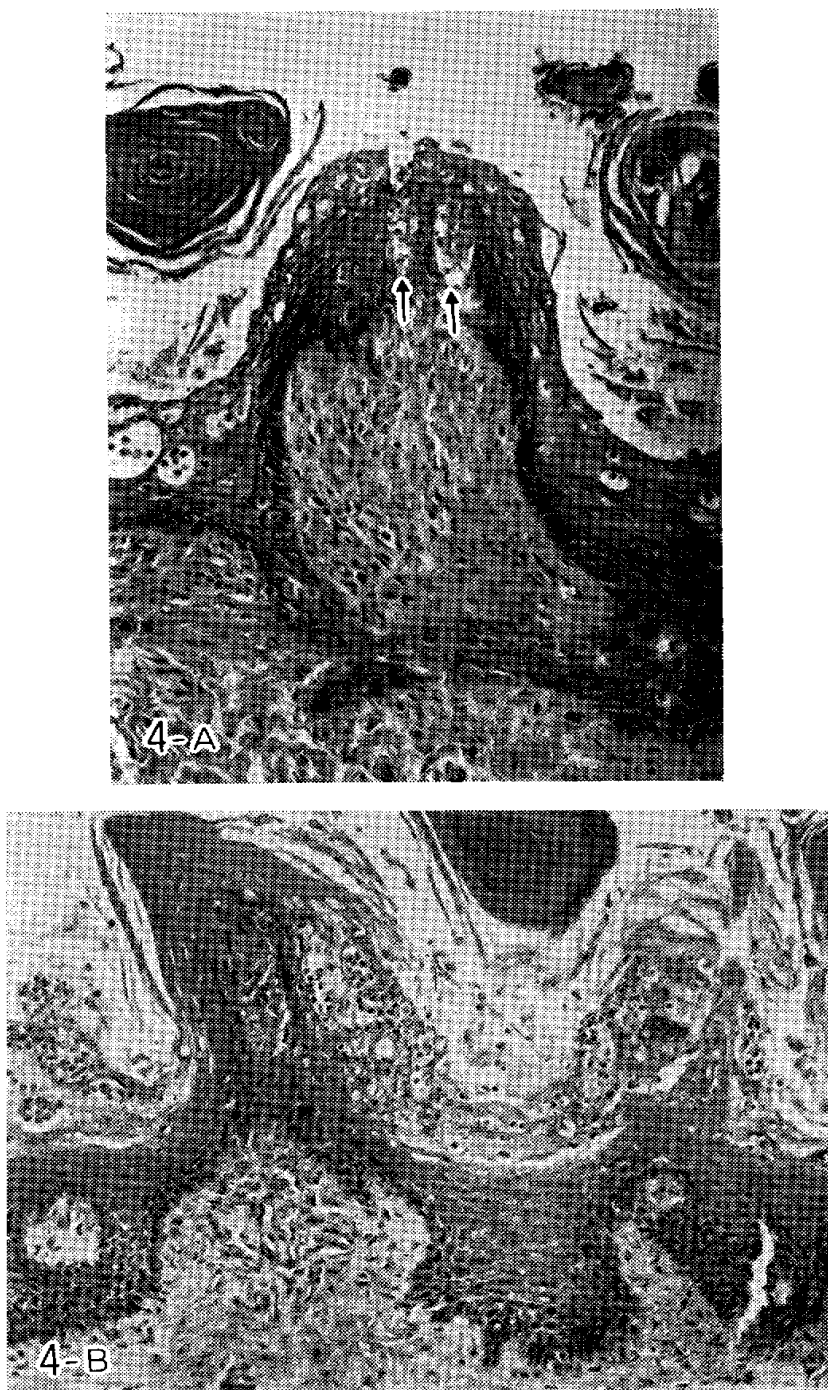

Figs. 4 照射後 3 日例の組織像
A ：a 部位の咠状乳頭（欠印：味蕾） と糸状乳頭尖端の一部 $5 \times 20$
$B$ ： b 部位の糸状乳頭 $5 \times 20$ 
(Fig. 4-A)。乳頭固有層における炎症細胞の浸潤は 至って軽い。

$\mathrm{b}$ 部位：上述の $\mathrm{a}$ 部位と大差なく, 系状乳頭上皮層 の半分以上は剝離または脱落しかけ，その中には浸潤し た炎症細胞の多くを観察できる（Fig．4-B）. 茸状乳 頭も a 部位のものと同じで，かろうじてその外観を保 ち, 残った上皮層中に崩壊寸前の味蕾を見出すことがで きる、乳頭固有層における炎症細胞の浸潤はほとんどみ られない位である。

c 部位： 基本的には $a ， b$ 部位のものと変わらな い. とくに苜状乳頭においては, 背面上皮の基底細胞層 にも部分的ながら，その形態の崩壊が見られ，同じく崩
壊途上の味蕾をかかえている像も芫出される、乳頭固有 層における炎症細胞は極く僅かである。

$\mathrm{d}$ 部位：有郭乳頭における上皮銪の態度は $\mathrm{a} \sim \mathrm{c}$ 部 位の乳頭のものと大して変らないが，上皮風の残留が幾 分厚く, それに応じて変性味蕾の細胞形態は茸状乳頭の ものよりもよく保守されている.しかしそれでも, 細胞 の種類の識別はほとんどできない。

照射後 5 日例：

a 部位を中心とする舌体左側中央辺の舌背わよび舌下 面粘膜面に黄褐色変化を示す領域力゙観察される。実体顕 微鏡下では上皮が部分的に剥離されて潰泀状所芫を呈す る。
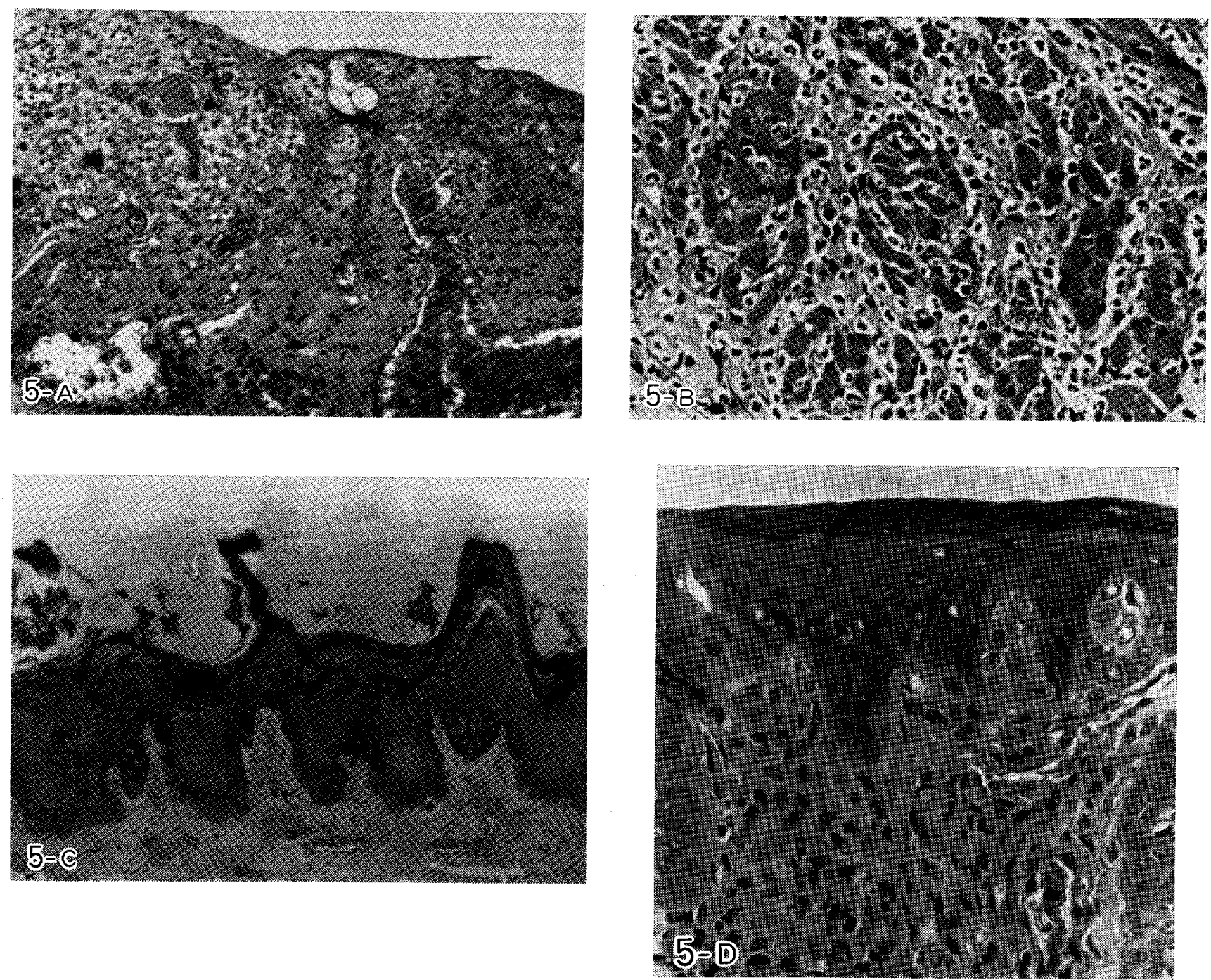

Figs. 5 照射後 5 日例の組織像
A： $\mathrm{a}$ 部位の上皮層の剥離と血管の拡張，充血 $5 \times 20$
B : a 部位における筋線維群の萎縮 $5 \times 20$
$\mathrm{C} ： \mathrm{~b}$ 部位における半崩壊状の糸状乳頭 $5 \times 10$
D：c 部位における茸状乳頭の味蕾 $5 \times 40$ 
$\mathrm{a}$ 部位：乳頭形態は全く認められず，かつ上皮風の ほとんぞは消失してしまって固有㬝面が直接露出してい る．部分的には，上皮の残遺物が僅かに留っているとて ろもある. 固有層全般にわたって炎症細胞が浸潤してい るが密集しているわけではない，血管の昖張，充血傾向 がみられる．また固有層の下部におよんでいる筋層の 一部に萎縮した筋線維群も認められる (Figs. 5-A， B).

b 部位： $\quad \mathrm{a}$ 部位に比べて障害度は軽いが, 系状乳頭 の上皮層上部が剝離, 脱落によって半崩壊に近い形で留 っている. 残った上皮層の半分近くは真正角化層で占め られる，有棘細胞の核の多くは染色性が低下し，膨化傾 向を示す (Fig. 5-C).

また, 茸状乳頭の高まりもほとんど姿を消し, 崩壊し た糸状乳頭とともに平坦化している．この場合の上皮層 でも, 真正角化層が增厚化し, 顆粒層を欠いて直ちに隣 接する有棘細胞層にす核の染色性の低下や，細胞によっ ては細胞と核の強い膨化を示すとてろもみられる。

$\mathrm{C}$ 部位：糸状乳頭，咠状乳頭ともにほぼ原型を留め るが，多少小型化したような外観を呈する. 角化上皮層 は依然として厚いが，扁平化した核の存在が著明で，錯 角化の状態を示している。

茸状乳頭の味蕾の分布数はコントロールと変らない。 構成細胞としての暗調細胞 (味細胞) と明調細胞（支持 細胞）の識別が容易なものとはっきりしないものがあ る.前者に抢いて，一部の明調細胞の基底側に空胞が認 められる。 a , b 部位に比べると，味覚器に対する障害 は比較的軽微である (Fig， 5-D).

$\mathrm{d}$ 部位： 観察した有郭乳頭の背面観はいずれも棈円 状であるが，乳頭の中心位に小窩があって，しかも哚 く，断面的には溝状をなすものが多く見られる。この海 上皮凰には，本来の周用瑇上皮層よりも沢山の味蕾が分 布する，味蕾は全般的にコントロールと翌らず，棈成す る各細胞も明膫に認められる。しかし，明調細胞の一部 に核の脱落像が観察される．乙の核の脱落像は，乳頭の 上皮層，とくに背面上皮層の表首から深層にかけても大 小の細胞核の膨化脱落がみられ，中には完全に核部が空 白化している細胞も観察される。

エブネル腺開口部の溝底上皮の一部に糜爛による上皮 の崩壊像がみられる．固有圓に分布する血管の多くは掋 張允血している.

照射後 9 日例

重篤症状样を呈するイヌの状態からも判断されるよう に，照射障害が最も強く現われる経過日数例である．粘
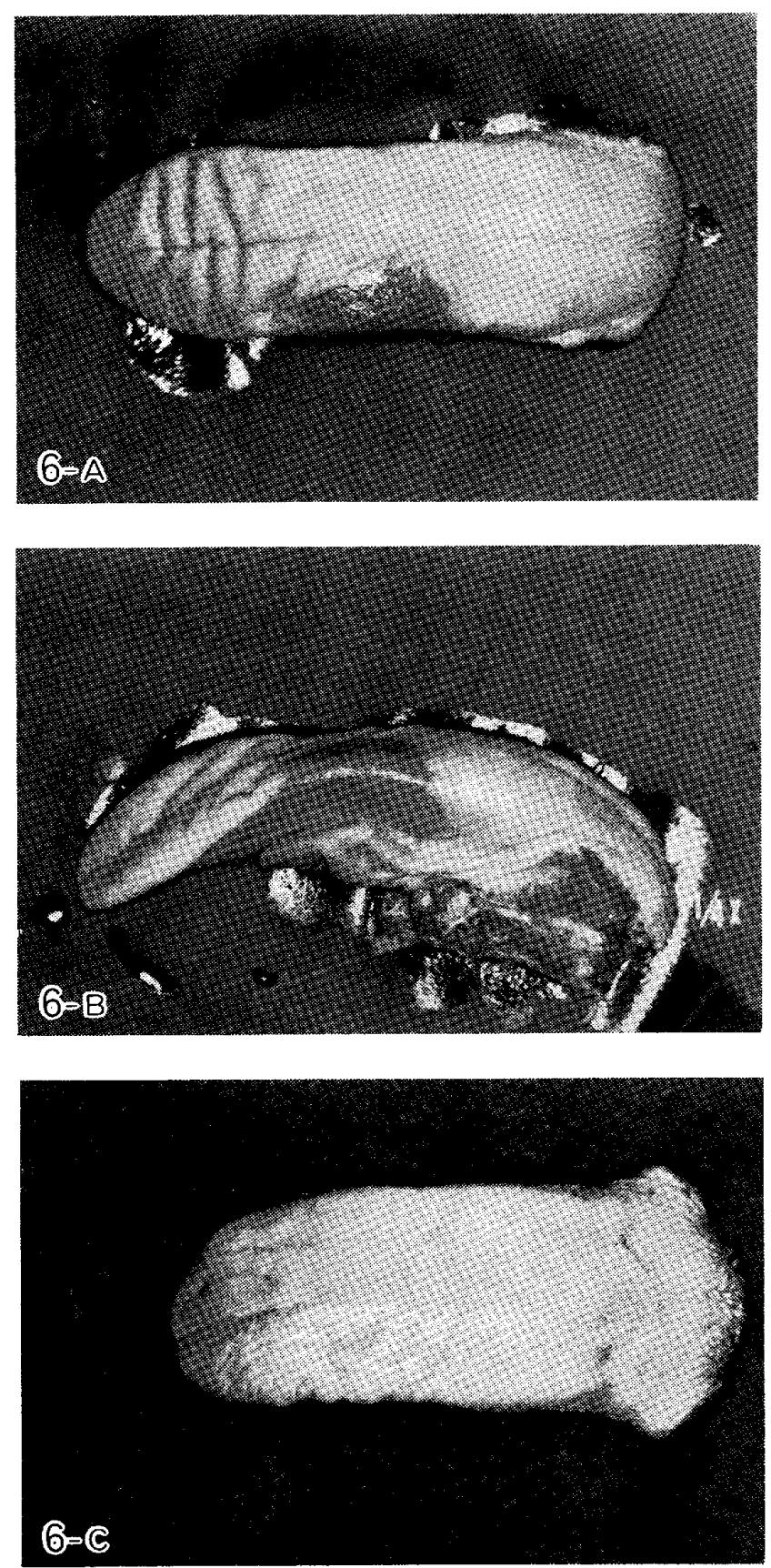

Figs. 6 照射による舌粘膜一部の変色
A：照射後 9 日例の舌の背面観
B：照射後 9 日例の舌の㑯面觬
$C ：$ 照射後15日例の舌の背面観

膜所見としては，Figs． 6-A，Bに示されるように， 舌の前後的中央辺にして, 左側舌背面汃ら舌下面にか门 ての黄褐色変化が顕著である.丁度, 焼けただれ面を思 わせる，実体顕微鏡下で観察すると，湿崵状所見を呈す る。

a 部位：5 日例と同じく, 糸状乳頭と苜状乳頭の姿 は全く認められない。つまり, 上皮層がすべて剥離され 

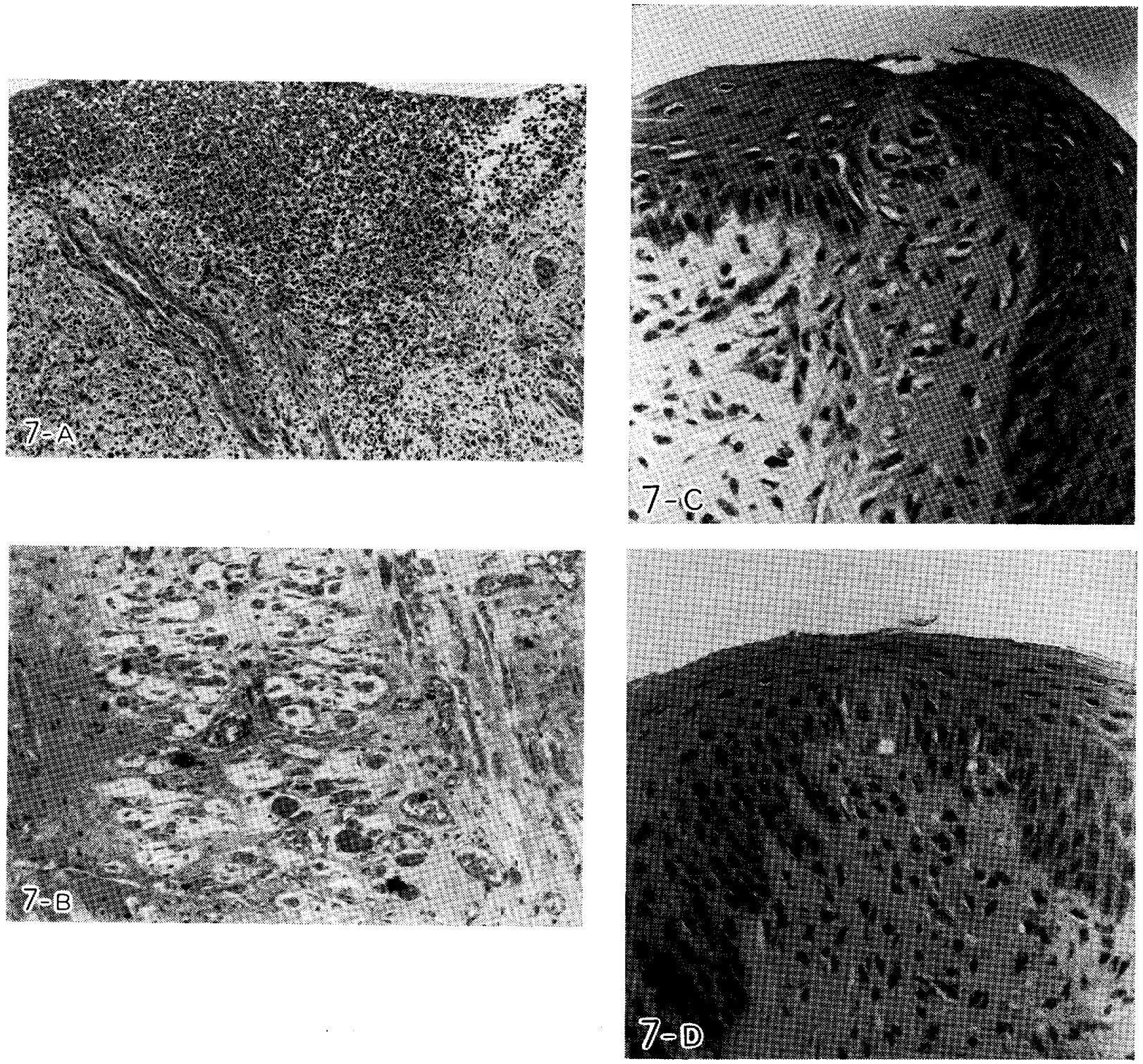

Figs. 7 照射後 9 日例の組織像
A：a 部位の上皮層が剝離し，固有層が直接露出して炎症細胞が密集する。
$5 \times 20$
B ：a 部位におりりる筋線維の萎縮 $5 \times 40$
$\mathrm{C}: \mathrm{b}$ 部位の茸状乳頭の味蕾 $5 \times 40$
$\mathrm{D}$ : c 部位の垚状乳頭の味蕾 $5 \times 40$

ているのみならず，乳頭固有層の突出もなく平坦な固有 風面が直接露出している．露出固有首の表周には炎症の 細胞浸潤が著しく密集し，典型的な糜爛像の形成をな す.固有層を形成する膠原線維束の配列も甚だ不規則で， 分布する血管もウッ血または充血状態を呈する，炎症細 胞の浸潤は固有層下の筋㟄間にも及び，比較的表層にあ る筋線維の多くはかなりの萎縮をなしている (Figs. $7-\mathrm{A}, \mathrm{B})$.

$\mathrm{b}$ 部： $\mathrm{a}$ 部位におけるような磔爛形成はなく，肉眼 的にはもちろんのてと，実体顕微鏡的にみてもあまり变
化のない粘膜面を示す. 従って, 切片標本上でも系状乳 頭と苗状乳頭の形態は大方保守されている．しかし, 詳 細に観察してみると，上皮の表尿には軽度の糜爛があっ て, 角化層の一部が剝離したり, 角化層の増厚傾向, 有 棘細胞層の消失傾向などが認められる.

乳頭固有層では血管の充血, 神経線維束の部分的断裂 㱚壞像がみられる。

茸状乳頭に扔ける味蕾の分布数も少な目にあり，多く

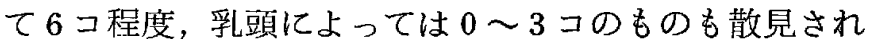
る、味蕾を構成する細胞形態のほとんどは歪み, 部分的 
な空胞化，細胞種の識別の困難なものが多い，比較的味 蕾細胞の整ったものでは，明調細胞の存在が不明瞭にな っている (Fig. 7-C).

$\mathrm{c}$ 部位：ての部位では $\mathrm{b}$ 部位でみられたような上皮 層の糜爛は全く観察されない，上皮の角化層は $\mathrm{b}$ 部位と 同じく厚目にある．そして，有棘細胞層の存在域がより 明瞭化している。

茸状乳頭 1 コ当りの味蕾は 4 〜 6 コぼ数えられる. 味蕾細胞の基底側に比較的大きな空胞を抱えている味蕾 が散見される（Fig．7一D）.

$\mathrm{d}$ 部位：有郭乳頭の形態，上皮層，固有層の状態は コントロールとほとんど変らないように見える。また， 味蕾についても特別な変化は見当らない.

\section{走査電顕的観察}

$\mathrm{a}$ 部位：コントロールでみられた乳頭様形態は一切 譛めることができず，焼け跡を思わせる段階相が顕著で ある. 切片標本での観察を裹付けるように，上皮層が消 失し, 固有層面に浸潤した炎症細胞が半球状の顆粒物と して集密した像が観察される（Figs．9-A，B，C）.

$\mathrm{b}$ 部位： 系状乳頭と茸状乳頭の形態は保守されてい るものの乳頭上皮面は平滑さがなく，上皮の鶨離や無数 の微生物（桿菌と寄生虫様体）の付着にて非常に不潔な 外観を呈する。もちろん，それによって味孔部の指摘は できない（Figs. 10一A，B）。

$\mathrm{c}$ 部位：乳頭上皮面は $\mathrm{b}$ 部位のものよりも疎造感は ない，つまり，微生物類の付着が少なく，平滑な上皮面 をもつものが多い、しかし，乳頭の全体観がしおれた花 をみるような精気のない，機能の大幅な減退を思わせ る. (Figs. 11-A, B).

$\mathrm{d}$ 部位：コントロールとほとんど変らない外観を呈 する。

\section{照射後15日例}

粘膜面の糜爛領域が部分的にかなり限局され，上皮の 修復状況もある程度識別できる。

ての部の粘膜面は多少凹凸があり，色調も他部と僅か に異っているため障害領域として指摘できる（Fig．6 $-\mathrm{c})$.

a 部位： 麻爛は 9 日例と同じく，上皮周がほとんど 見られず，極く僅かの上皮残骸を留める領域と，角化層 だけを欠いた上皮風領域が観察される，後者は上皮の修 復部を現わす部にして，まだ乳頭樣の高まりはないが， 固有層への比較的長い上皮突起の伸長発育がみられる。 上皮層の表層は顆粒層が占めるが，細胞間隙の増大や細 胞の空胞化が目立ち，その中には数コまたはそれ以上の
遊走細胞の浸潤が依然として多く観察される（Figs. 12 $-\mathrm{A}, \mathrm{B}, \mathrm{C}$ ) .

b 部位：上皮層はもろんのとと, 乳頭形態の完全回 が認められ，既に愿い角化渞の一部が剝離しかけてい る. 苜状乳頭の上皮層も角化層の增厚に上って全体の厚 さを増している。しかし，上皮層の一部には遊走細胞の 浸潤が認められる。味蕾の数や大きさは，コントロール のものに近いが，一部の構成細胞，とくに明調細胞に僅 かな萎縮傾向がみられる（Fig. 12-D）。

$\mathrm{c}$ 部位： b 部位之同しく, 全搬的に角化層が厚く, 表面上皮の剶離の状況もコントロールとほとんど変らな い状況を示す。

$\mathrm{d}$ 部位：有郭乳頭の外形，上皮層，固有首の状況は コントロールと変りない，しかし，味蕾の分布が乳頭背 面中央の小简上皮中のみに集中儿，両側方溝の上皮中に はほとんど存在しない，味蕾の一部には，細胞の萎縮や 核の濃縮を示すものが認められる。

照射後35日目

この段階になると，粘膜面の照射障害による変色領域 は識別することはできない，つまり，肉眼的にはやや粗 造感を呈する以外はコントロールとほとんど変らない．

$\mathrm{a}$ 部位： 正常の乳頭形態を保っているが，上皮風に おける角化周が依然として厚目にあり，顆粒層の存在が はっきりしない，一部の糸状乳頭上皮層には，角化層か ら有棘層にかけて，細胞間隙の増大や細胞の水腫性変性 を示すと乙ろが見られ，その多くには遊走細胞の入りと みが観察される。茸状乳頭の上皮㬝には，そのような変 性像は認められないが，顆粒層から有棘層にかけての細 胞の一部に，核の染色性低下や肥大化がるられる。味蕾 においても，構成細胞の崩壊を示すものが依然として みられ，なかには遊走細胞で満されているのも見出さ れる.固有層に打ける炎症細胞もまた若干観察される (Figs. 13-A, B).

$\mathrm{b}$ 部位： $\mathrm{a}$ 部位と同じく, 糸状乳頭における角化層 は厭く，細胞間隍の増大などみられるが，水腫性変性を 示す上皮圓は全く観察されない，茸状乳頭においては， $\mathbf{a}$ 部位のもの之同じく，顆粒層から有棘層にかけての紐 胞の一部に，核の染色性低下と肥大傾向を示すものが認 められる。味蕾の分布は正常と変らないが，味蕾細胞の 萎縮傾向が依然としてみられる (Fig. 13-C).

$\mathrm{c}, \mathrm{d}$ 部位：いずれも，コントロール所見と変らな い (Fig. 13-D).

照射後 60 日例

$\mathrm{a} \sim \mathrm{d}$ の各部位とも, コントロールの正常組織像と変 

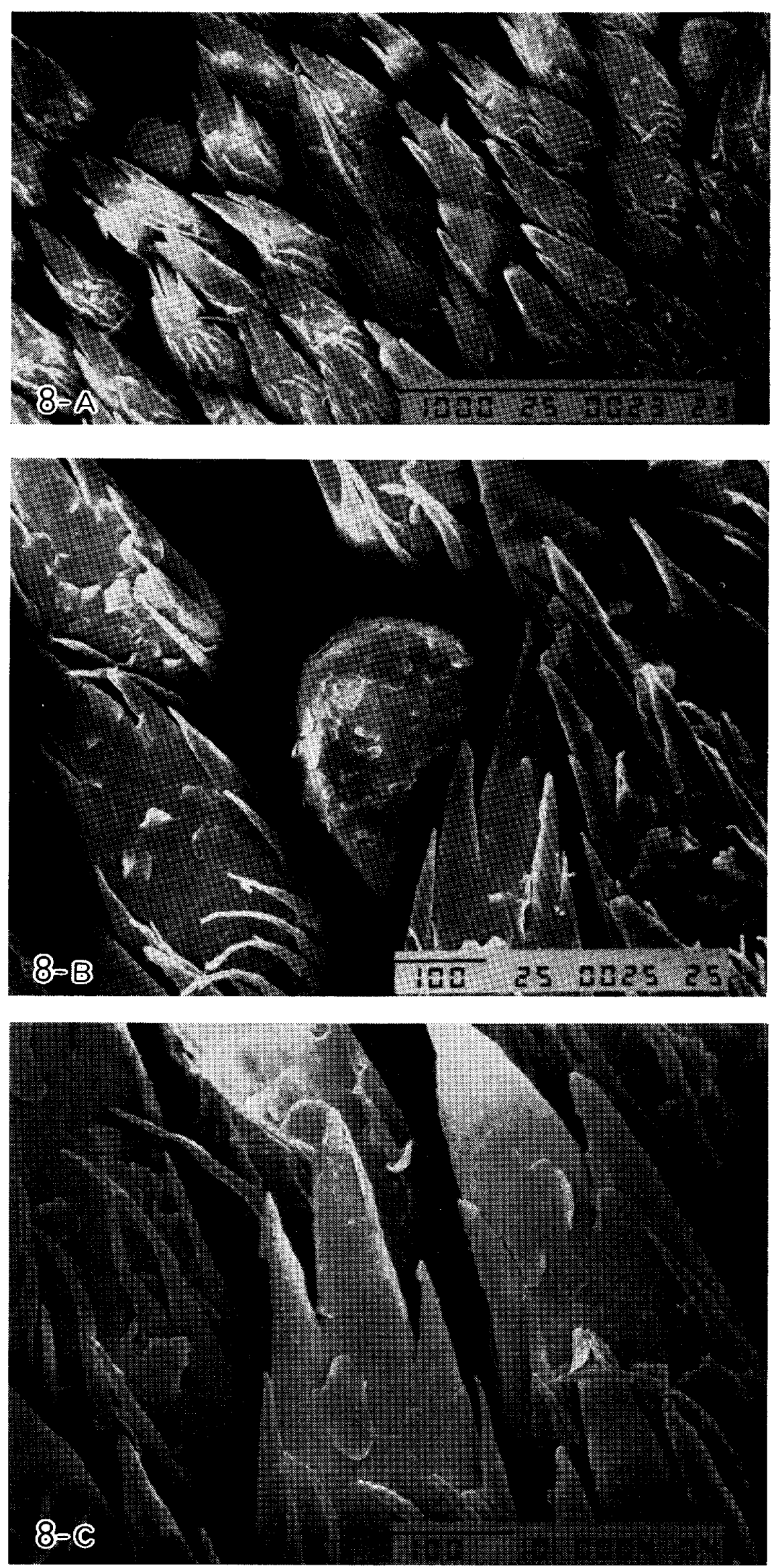

Figs. 8 対照群の糸状乳頭と茸状乳頭のS E M 像 
九州柬会誌 第 40 巻第 6 号 1986
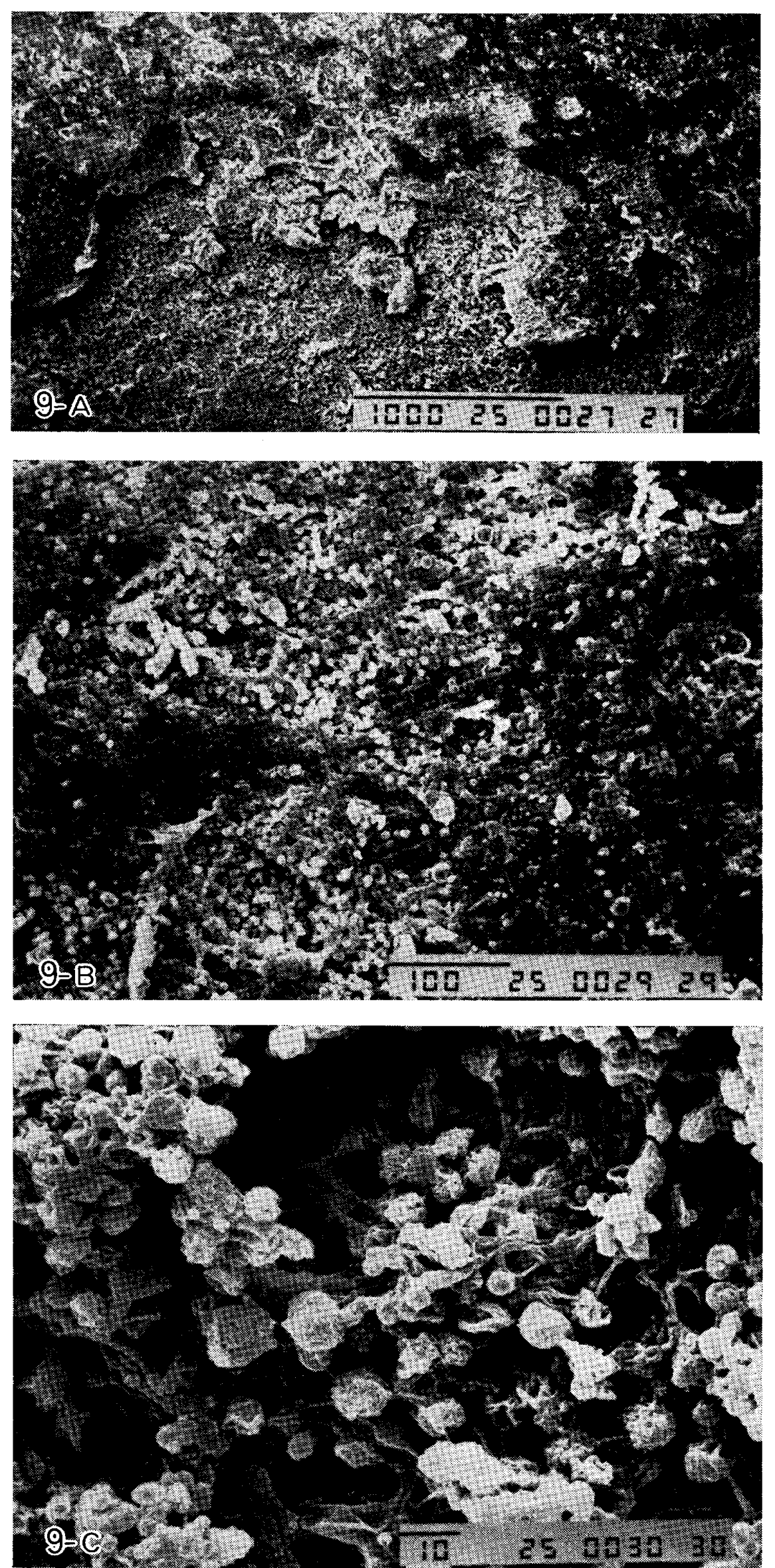

Figs. 9 照射後 9 日例の $\mathrm{a}$ 部位焚爛面 のS EM像

$\mathrm{A}$ ：上皮の部分的変態残留と 固有層表面

B ：固有層表面の炎症細胞群 $\mathrm{C} ： \mathrm{~B}$ の一部拡大 

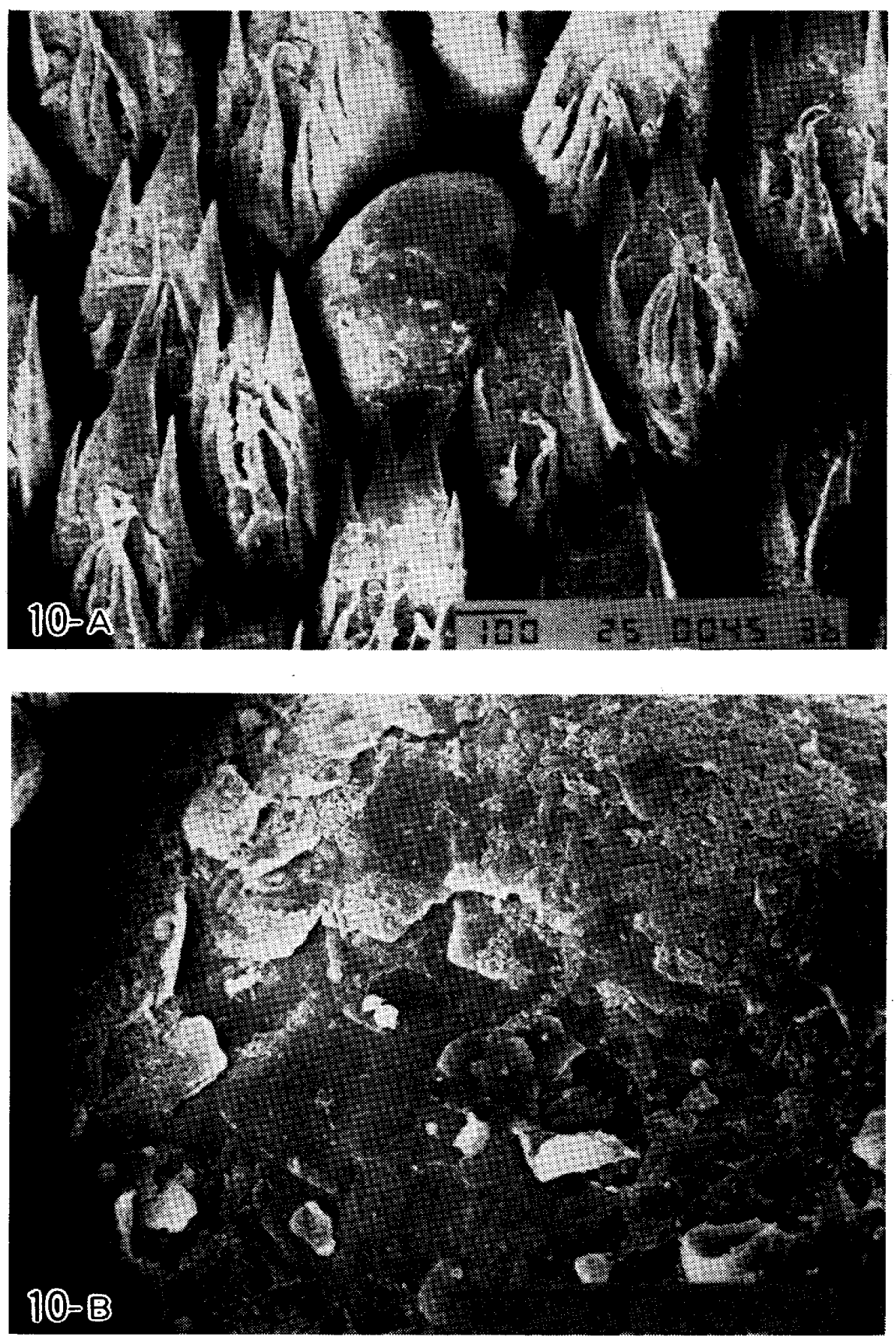

Figs. 10 照射後 9 日例の b 部位の S E M像

乳頭形態が多少ゆがむとともに，その表面は不挲に して無数の細菌や寄用虫様微生物がむらがっている.

らない。

\section{総括および考察}

Conger (1973）'は臨床例において, 放射線照射前, 照射中および照射後におけるシュクローズ，塩酸，キ二 ンなどの味覚閾值の変化を計測した。それによると， 味感度の消失は照射量がますにつれて徐々に進行, 240 $\operatorname{rad}$ で辛味が，400 rad では酸味の感度が半減し，3,000 $\operatorname{rad}$ を越えると急速になり，ティカップにスプーン約25 杯山盛分の砂糖に匹敵するシュクローズ夜をかろうじて 甘いと感し，家庭用の食酢の濃度の1.5倍の液をスッパ イと感し，さらにはビン詰の炭酸キニン水濃度の 1,500 倍液を苦いと感じるという。そして, 味感度の10倍回復 は, 照射後20〜60日以内に，完全な正常回復は $60 \sim 120$ 日以内と述べている，過度な照射は，味覚消失に近い障 害を与えるととを示されたわけであるが，それを病理組 

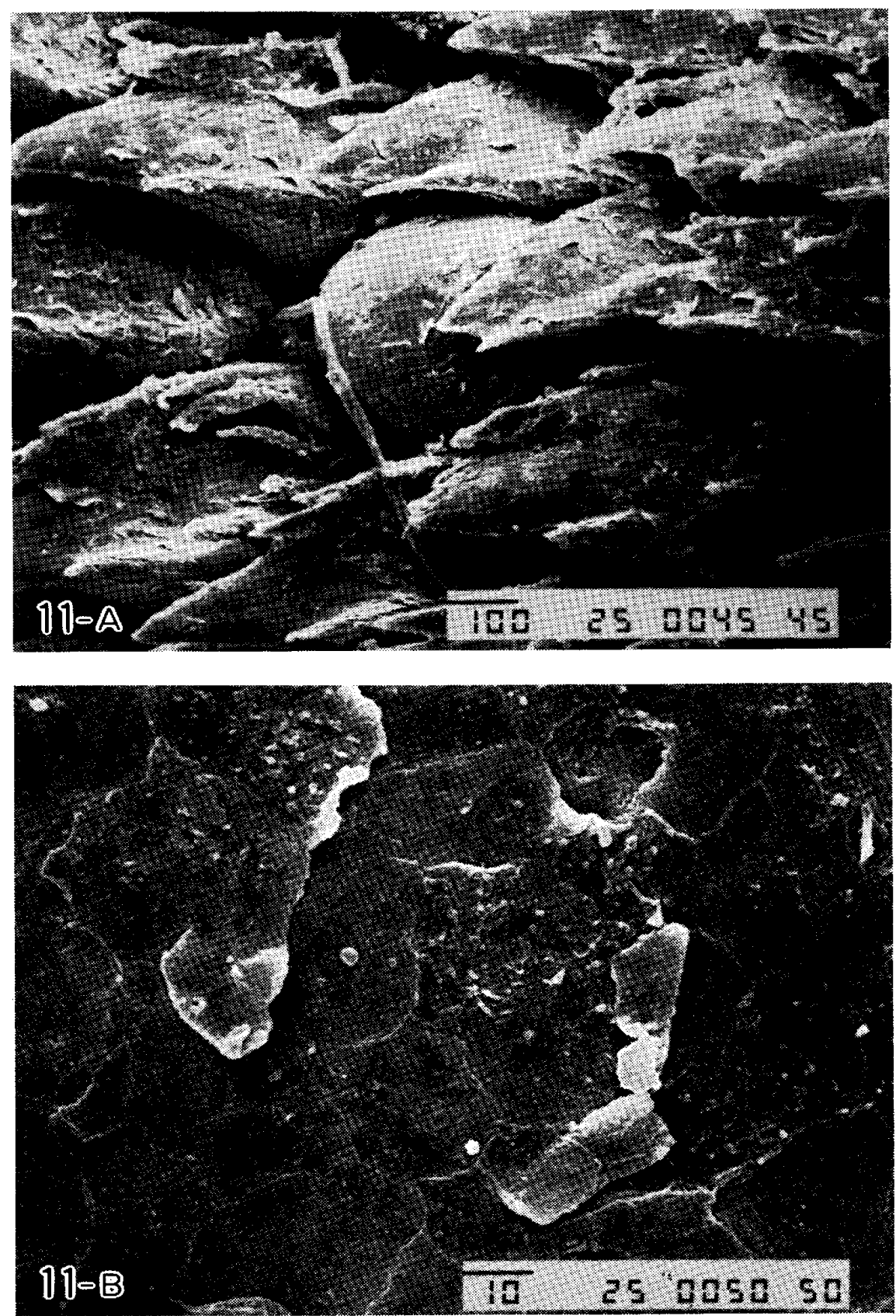

Figs. 11 照射後 9 日例のC 部位のS E M像
A：少し形態がゆがみ，表面が粗造感を呈する糸状 乳頭と咠状乳頭
B：茸状乳頭表面の拡大

織学的にみるならば，味覚器官のうけるダメージは富田 ら (1981) ${ }^{7}$ の報告にもあるように，相当なものである ことが想定される．従って，その自然回復もかなり手間 どるととになる。味覚器が直接障害をうける前の, 口腔 粘膜全般の障害について文献的に言及してみることにす る。

口腔領域悪性腫瘍の放射線治療によって惹起される 早期の障害としては，放射線口内炎（radiostomatitis or radiomucositis）があげられている.これの臨床に 関しては，既に戦前時代から Coutard (1932) ${ }^{15)}$ によ り報告され，その後の諸報告に関しては Rubin ら（19 68（16)によって成書に集約されている．放射線照射に伴 う口腔症状の主なものについて次のように述へている.

1 週末 $(1,000 \sim 2,000 \mathrm{R})$ : 有郭乳頭の突出, 味反応 変化.

2 週末 $(2,000 \sim 2,400 R)$ : 粘膜痛, 䋩下痛, 口腔の 

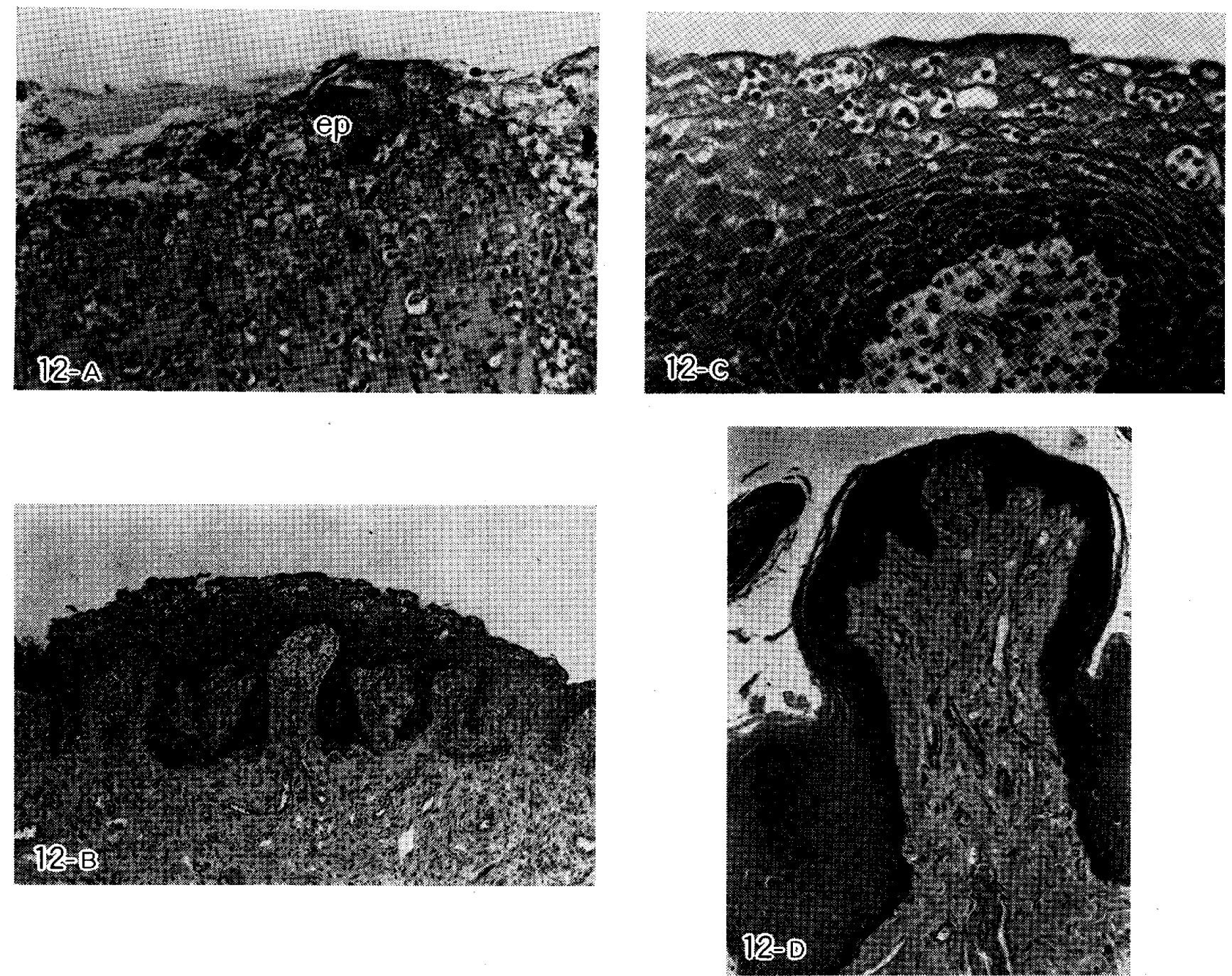

Figs. 12 照射後15日例の組織像
A：a部位における残留上皮（ep） $5 \times 20$
B：a 部位に抢ける上皮の増生 $5 \times 10$
$\mathrm{C}: \mathrm{B}$ の一部㹡大 $5 \times 40$
$\mathrm{D} ： \mathrm{~b}$ 部位の茸状乳頭と味蕾 $5 \times 20$

乾燥感, 味覚の減退, 紅斑.

3 週末 $(3,000 \sim 3,600 R) ： の$ ぞ渴き感，掑食困難， 唾液の粘调度の増加, 粘膜炎症の拡大.

4 週末 $(4,000 \sim 4,800 \mathrm{R})$ : 前週症状の程度を増し， 上皮剝離.

5 週末 $(5,000 \sim 6,000 \mathrm{R})$ : 潰瘍上の偽膜形成.

諸条件の相異などからイヌ (著者) やモルモット（代 田，1932１7に現われた症状を単純に比較することはで きないが, 少くとも臨床的に認められる動作緩慢, 食欲 不振（摄食困難，堅目の食物をさける），全身衰弱感な どは共通的症状として指摘できる。物言わぬ動物にとっ ても, 㿥下痛, のど渴き感, 味覚の変調などがあったて とと思われる。
一方，放射線口内炎に関する実験的研究として，代田 $(1932)^{17}$ はモルモット,大竹(1958) 18) はウサギ, Dale $(1953)^{19}$ はラット, Vos ら $(1959)^{201}$, Shapiro ら $(1960)^{211}$ ，Goepp ら (1969) ${ }^{22}$ およよ゙太田 $(1973)^{91}$ らはマウスについてそれぞれ行っている.ラジウムを使 用した代田を除くと, 彼らの実験は $2,000 \mathrm{R}$ 以下の頭部 または全身照射によるもので, 舌粘膜を含めた口腔諸組 織に及ぼす障害をいろいろと述べている，その中で，モ ルモットについて試みた代田（1932）の病理組織学的記 述がかなり具体的であり，他の研究者が述べている諸症 状のほとんどが含まれているので, それらを症状の軽度 のものから順にあげると，次のようになる。

。上皮尿から筋層にかけての円形細胞の浸潤. 

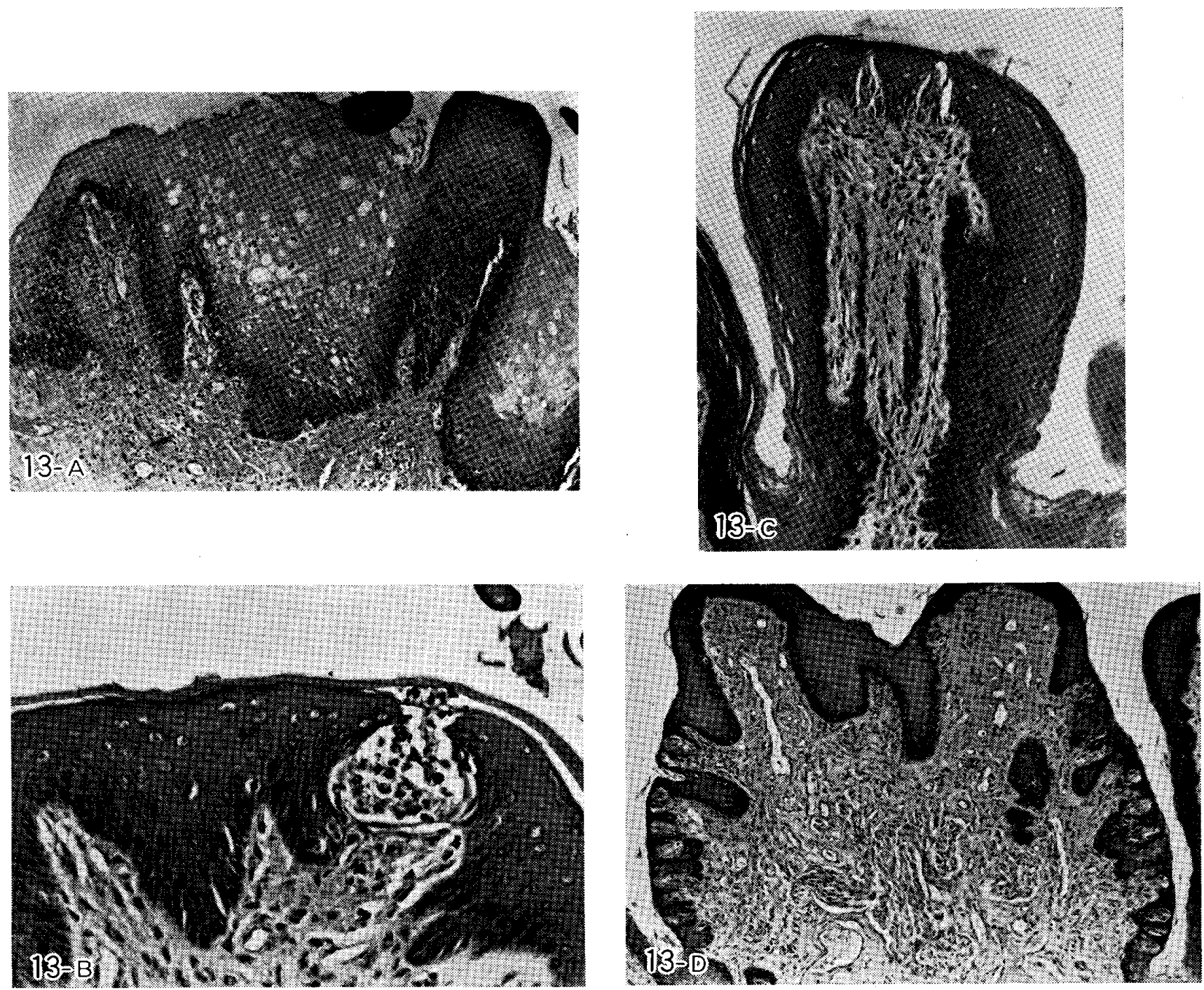

Figs. 13 照射後35日例の組織像
A： $\mathrm{a}$ 部位の糸状乳頭上皮圈 $5 \times 20$
B ：a 部位の茸状乳頭の味蕾 $5 \times 40$
$\mathrm{C}: \mathrm{b}$ 部位の茸状乳頭の味蕾 $5 \times 20$
$\mathrm{D} ： \mathrm{~d}$ 部位の有郭乳頭と味蕾の分布 $5 \times 20$

。錯角化，一部の剝離，下層上皮細胞の膨大，空胞形 成.

。上皮層の壊死, 糜爛, 潰瘍形成, 膿性滲出物の付 着, 施皮の形成.

。固有層の糜爛，乳頭の壊死脱落，結合組織細胞の核 膨大, 濃縮, 崩壊.

。筇線維の菱縮, 横紋の消失, 溷濁腫張, 蠟様変性.

以上の病理組織学的所見は，マウスを主とするケッ歯 動物におけるすのであるが，乙れに中動物としてのイヌ の舌粘膜の障害を対比するのは照射量の相異はもとよ り, 照射方法, 舌乳頭の発育形態の違いなどで正確さを 欠くきらいはあるが粘膜としての組織構成は同一である
ので，障害程度の比較には大して差支えないものと判断 される。

正常なイヌの舌の外観および舌背粘膜に関する肉眼的 および光顕的観察知見は Miller ら (1967) 23)や Adam ら $(1970)^{24}$ の成書に詳しく述べられている。 また，舌 乳頭の走査電顕的微細構造については藤ら (1982) ${ }^{25}$ に よって報告されている。しかし，乙れらの記載はすべて 成犬についてのものである，本実験に使用した幼犬とは 舌乳頭などの発育度に多少の相異あるので注意を要する ところである、以下に，著者の実験による放射線障害を 総括してみると，次のようになる。

照射後 9 日目にて, 照射筒に最も接近している 
の放射線障害が最も激しい，粘膜面の色調変化を始めと し，上皮層の部分的な糜爛形成，固有層における炎症細 胞のび漫性浸潤, 固有層に近接する笳線維の萎縮, 横紋 構造の不明瞭などが主な症状としてあげることができ る. b , c 部位の障害の程度は $\mathbf{a}$ 部位に比べると甚だ軽 微といってよい，味蕾についてみると，分布の減少傾 向, 味蕾細胞の萎縮変形, それに伴う細胞の種類の識別 困難，明調細胞の減少傾向が指摘できる。

照射後 5 日目は，9日目に比べると全般的に障害は軽 い.しかし，部位によっては逆に障害が強いところもみ られる。照射後 3 日目では，さらに一段と軽微となる が，味蕾の基本的な変化はあまり変らない，照射後 1 日 目では，ほとんどコントロールと変らない，照射後の経 過日数の長い15日目になると，9日目にみられた糜爛の 辺縁上皮組織の修復徴候が認められる，それに応じて， 味蕾にも細胞の萎縮が減少傾向を示す，さらに長い照射 後35日目に至ると, 諸組織はコントロールとほとんど変 らない構造を呈する。

代田 (1932，モルモット ${ }^{17}$ ，大竹 $\left(1958\right.$, ウサギ ${ }^{183}$ ， 太田 $(1973 \text { ，マウス })^{9 \prime}$ による動物実験に扔いて，いず れも実験直後に変化はなく，時間経過につれて障害が現 われ, 大体一週間前後より潰禓形成などの障害が顕著に なるととが大体一致している．著者の場合の 5 日目と 9 日目の中間になるが，彼らの照射後の追跡観察が 7 日以 降までに及んでいないので正確な比較対照にはならない が，大方の障害出現時期を現わすものとみてよいと思わ れる．このような発現の仕方は，放射線特有の作用機序 によるとされるが，概して照射量に比例して強くなる．

一方，放射線による粘膜障害の回復はどんな経緯をと るか，とれに関する文献的記述は案外と少ない。代田 (1932) ${ }^{17}$ ) の実験（イヌ舌粘膜とモルモット外皮の窝蝕） によると，口腔粘膜の治癒機転は外皮よりもはるかに速 く，また舌粘膜は煩粘膜よりも速く治癒るす。ところ が，放射線障害による粘膜の治㾑機軽ははるかに遅く， 照射後 $2 \sim 3$ 週間は治癒の所見はみられず，照射後30〜 40日にして始めて炎症消退，上皮の新生を認める，と述 ベている．著者の実験における照射後35日例に匹敵する 所見であるが，残念ながら回復機転のスタート，即ち治 癒の兆候についてはあまり触れていない，しかし粘膜上 皮の中の味蕾については，2３の文献に記述がみられ るので，以下に味蕾の障害を述べる中でとりあげてみ る。

谷川 $(1963)^{2)}$ は臨床的研究で，味覚障害は 1,000〜 4,000 Rで現われ，3,000〜 7,000 Rで味覚消失を来たし，
その回復は照射後30〜40日を要すると述べている．マウ ス頭部に1,500R照射実験を試みた Conger ら(1969) ${ }^{81}$ によると，味蕾の数，味蕾の細胞数は大体照射後 9 日で 最少となり，10日以降で回復が始まり，20日で回復す る。また，臨休的には $(6,000 \mathrm{R}$ 照射) 照射後 60〜100 日にて味覚が正常に回復する，と述べている．さらに Conger ら (1973) ${ }^{4)}$ は本総括のぼう頭にも述べたよう に，3,000R を越える照射では，失われた患者の味感度 の10倍回復は照射後 $20 \sim 60$ 日以内, 完全回復は $60 \sim 120$ 日以内と報告している。一方, 魚類 (メダカ, 1,000R） の味蕾について検索した Ghoneum(1983)11'によると， 味蕾の明調細胞（支持細胞）の方が放射線の感受性が高 く，1日目で既に数の減少がみられ，5日目で著しく減 少する，暗調細胞の方はさほど影響をうけない，10日目 で明調細胞は再生し，コントロールとほとんど変らない ようになると述べている．著者の実験したイヌでは，大 体照射後15日以降に回復の兆が認められている．照射量 その他の条件によって一定した回復日数は得られていな いが, 大方の回復スタートは臨床例では照射後 20 日以 降, 動物では10日以降, 完全回復は臨床例で60日以降, 動物でははっきりしない. Conger (1969) ${ }^{8)}$ によるマウ スの照射実験で，味蕾細胞の消失率およびその回復は， 臨床例の場合の味感度の减退と回復の割合はよく合致す るという興味あるデータを示した。これによると，ヒト も動物も一定の照射条件のもとでは同じであることを示 すものといえよう。

著者による味蕾に関する所見を総括してみると, 照射 後 1 日目から味蕾細胞に僅かな萎縮がみられ，3 日目に かけて強くなる傾向を示した．それに忘じて味蕾の細胞 配列がゆがみ, 味蕾によっては細胞の種類の識別も難し くなった。 pyknosis を示す細胞も認められた。照射後 5 日目から9 日目にかけては, 上皮剝離のため味蕾を全 く久くところ (a 部位), 味蕾数の僅かな減少, 味蕾細 胞の萎縮, 細胞識別困難, とくに明調細胞の不明膫, 核 の脱落などがみられた，照射後15日目以降は，他の粘膜 組織と同しく味蕾の諸変化も回復するものと思われる が, 微妙な回復変化ははっきりと指摘はできず, 光顕的 には依然として味蕾細胞の萎縮, pyknosis など認めら れ，照射後 35日目でも細胞崩壊を示す味蕾む観察され た.照射後 2 カ月目のむのでは, コントロールとほとん ど変らない味蕾像を認めることができた，以上の総括所 見も，各部位的に詳しくみると多少まちまちな面むみら れる。しかし，照射筒に最も近いa部位の味蕾のうける ダメージ，他組織と同じく最も強いことには変りはな 
い. 文献と比較してみて, 味蕾の数的減少, 細胞萎縮, pyknosis, 細胞の部分的空胞変性, 明調紲胞の不明膫 など，類似した障害変化像を指摘することができたが， 障害の強い照射後 5 日〜15日目の $\mathrm{a}$ 部位では味蕾どてろ か, 肝心な上皮組織が一部の固有層組織ととも亿消え失 せてしまっているから，その部位についてだけみると， 味蕾の数, 味蕾細胞の数の減少は $100 \%$ に限りなく近いも のとみてよい，味蕾細胞が萎縮変性を起すと，細胞形態 がゆがむと同時に，大抵明調性の細胞の存在がはっきり しなくなる。つまり消夫し，暗調性の細胞だけになって 見える。ささに進行すると, 暗調細胞自身の識別も困難 になる．太田(1973)はマウスにて，支持細胞 (明調細胞) が不鮮明になることを指摘し, Ghoneum (1983) も先 亿触れたように，明調細胞の方が放射線感受性が高く， 暗調細胞の方はそれほど変化をうけないとし，照射 1 日 目から数を減少し始め，10日目から再生すると，かなり 具体的に示した，乙の上うな事実は，味蕾の支配神経切 断にて生じる現象にある程度似ている．北村 $(1965)^{26}$ の光顕的切断実験（ラット）によると, 先づ味蕾内の神 経汇変性障害が切断後 12 時間目に現われ，次いで味蕾細 胞のうちの支持細胞（明調または II 型）の減少が目立 ち，味細胞（暗調または I 型）と中間型の細胞はそのま まであると述べている．Fujimoto ら $(1970)^{27)}$ も同じ ような実験 (ウサギ) を電顕的に検索して，似たような結 果を観察している，乙れらの先人の研究から，Conger (1969） ${ }^{8)}$ は味蕾細胞に対する放射線障害も支配神経に 対する直接障害（味蕾の栄養的維持機能を損う）ではな いかと推察したが，神経染色学的にいろいろと検討して も何ら証明できるものはなかったと報告している。しか し, 別の観点から Conger ら (1973） ${ }^{41}$ は味感覚の消失 メカニズムを微細構造学的に示した。即ち，味蕾細胞

(taste cells) の味毛あるいはその表面に対する照射障 害であるとし，マウスで実験的に microvilli を有する 細胞尖端が erosion をうけているととによるととを実証 した.

Conger ら $(1973)^{41}$ による, microvilli のダメージが 正しい実証であるとするならば，明調細胞のみならず， むしろ microvilli がよく発達している暗調細胞の障害 の方が大きく出現しなければならない筈である，従っ て，きめ手になる証明には至っていないように思われ る。味蕾内の神経終末との関係も含めて, 微細構造的面 からの再検討が必要と考える。

最近, 楊 $(1981)^{12)}$ 始めとする池田 $(1985)^{28)}$ ，久 芳 $(1986)^{291}$ ，河井 $(1986)^{301}$, 永山 $(1986)^{31}$ らはイ
又を使っての口腔諸組織の放射線に関する興味ある研究 を行っている，楊は，有蒾顎への $3,000 \mathrm{R}$ 照射にて歯頸 部歯肉に漬瘍形成をみたが，無歯䈯の同一条件では漬瘍 形成は認められなかったと，歯の有無による影響の相違 を強調している. 乳歯列期の口腔組織を観察した池田 は, 照射後 8 日から15日までが最も生体反応が激しい時 期にして, 歯肉に発赤, 潰揚形成, 易出血性がみられ, 照射後 2 カ月にて潰場は回復したと述べている，久芳は 幼犬の口腔組織を観察して， 1 週目から 3 週目にかけて 柬肉粘膜の色素脱失, 曾肉の発赤, 3 力月目上り歯肉の 謴瘍, 壊死, 䨑槽骨の露出, 柬牙の動摇などについて述 べている．河井は同じく幼犬の下顎骨をみて，骨能道は 1 週目ですでに脂肪髄の形成が認められ，8 月至でほぼ顎 全体が脂肪髄を呈していたという．幼犬の歯髄と歯根膜 を主に観察した永山は次のように報告している．照射後 1 力月〜 2 力月にて象牙芽細胞に萎縮がみられ，歯骾の 一部は硝子椂変性, 石灭宍性を示す. 歯根膜のシャーピ 一線維は走向が不規則になり, 線維芽細胞が大幅に減少 する. 照射後 4 力月で象牙牙細胞の萎縮，消失が著しく なる，照射後 8 力月で，料髄の細胞核や，線維，血管な どがほとんぞみられなくなり, シャーピー線維の大部分 も消失するという。

以上の諸報告から分るように，実験動物の成熟度や口 腔の軟組織の違いによってはかなりの放射線障害の差が 現わされている．とくに，同じ軟組織でも歯質または骨

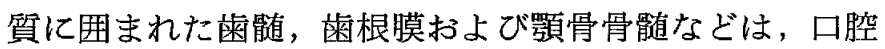
に直接露出する歯肉, 煩, 舌粘膜などと違って照射後 8 カ月までも強く障害が及ぶことは, ダメージをうけた各 組織の形成細胞の回復機転が遅々として進行しないため によるものだろうか. 生駒（1973（ ${ }^{321}$ 亿よると，放射線 の直接作用による組織の変性と, 血管系への障害による 間接的影響も強いのではないかと述べている。

本実験にて対象になった舌乳頭は, 実験成績で述べた ように，他の口腔諸組織に比べて放射線に対する感受性 が高く, 一方, 照射後の回復力がかなり早い組織である こと, そして, 上皮の中で高度に分化した味覚器の形態 と機能の完全回復だけは少しズレることなどについて指 摘することできた。

\section{結 論}

幼犬（19頭）の舌背粘膜に X線照射（1,000 R $/ 3$ 日 間隔 $/ 3$ 回) を試み，照射後 1 日目，3日目，5 日目， 9 日目，15日目，35日目抢よび60日目の各々について光 顕的, 走查電顕的 (SEM) に観察した。 得られた主な 
知見は次のとおりである。

1. 該動物は照射後 5 日目から動作緩慢, 食欲不振己 なり飼料約 $1 / 3$ 残す. 8 日目から 9 日目にかけて,さら に目ヤ二, 流涙が多くなり衣弱感增す.15日目から回復 的兆候を示す.

2. 照射後 9 日例におういて, 照射筒に最も近い領域の 舌粘膜に著しい黄褐色変性が観察される。

3. 黄褐色変性部は, 顕微鏡的には糜爛形成部にし て, 舌乳頭の姿はもちろんのてと, 上皮層が全く認めら れない，炎症細胞の浸潤が顕著な粘膜固有層が直接露出 している。

4. SEM でこの毵爛部観察すると, 固有層表面に遊 出した無数に近い炎症細胞群や上皮層の部分的残がいな ぞが入り混じった像としてみるととができる。

5. この部の粘膜固有層における結合組織線維は配列 が乱れ，血管のほとんどは充血拡張している．本層に及 んでいる筋線維群には萎縮が認められるとともに，横紋 構造が不鮮明になっている。

6. 変色粘膜に直接隣接する通常色を呈する粘膜領域 の舌乳頭は，その形態を保守しているが, 上皮層の一部 に糜爛, 固有層も含めて水腫が観察される.SEM でみ ると, 系状乳頭, 草状乳頭とも多少外形を变容させ, か つその表面が粗造で，無数の微生物や寄生虫様構造物が
密集している。

茸状乳頭の味蕾は数の減少, 味蕾 細胞の萎縮, 減少 (主に明調または支持細胞), 空胞変性などがみられる。

7. 照射後 5 日例と15日例における変色領域は 9 日例 よりかなり限局されているが，後者は上皮層の修復によ るものである．それに隣接する健康色領域の炎症は軽 认.

8. 照射後 3 日目， 1 日目と照射日に近いほど障害の 度合が軽く，とくに1日目ではどの領域もコントロール と変らないように見える。

9. 照射後15日以降の粘膜上皮の増殖回復に応じて, 味蕾の数, 味蕾細胞数の回復む認められるが, 細胞の萎 縮は依然として認められ，配列が不規則である．照射後 35日例になっても，味蕾によっては炎症細胞の浸潤がみ られ, 完全な正常像への回復は照射後60日以後である.

稿を終えるに臨み，御指導と御校閲を賜りました嶋村 昭层教授と大庭 健教授に深甚なる感謝の意を表しま す.また本研究に当って, 赛験材料の一部の提供をうけ ました, 本学小児䨑科学講座木村光孝教授に满腔の謝意 を申し上げます.さらに, 常に適切なる御教示と御協力 を賜りました口腔解剖学第 2 講座と歯科放射線学講座の 各先生方に厚く御礼を申し上げます。

\section{引用 文 献}

1) Kalmus, H. and D. Farnsworth : Impairment and recovery of taste following irradiation of the oropharynx. J. Laryngol. Oto. $73: 180-182,1959$.

2 ）谷川一夫：放射線による味覚障害の臨床的ならびに実験的研究。日医放会誌 $23: 704-712,1963$.

3) Schaupp, H., Bertram, K.J. und Schulz-Freywald, G. : Radiogene Geschmackschäden. $Z$. Laryng. Rhinal. $51: 336-343,1972$.

4 ) Conger, A.D. : Loss and recovery of taste acuity in patients irradiated to the oral cavity. Radiat. Res. $53: 338-347,1973$.

5) Mossman, K.L. and R.I. Henkin : Radiation-induced changes in taste acuity in cancer patient. Int. J. Radiat. Oncol. Biol. Phys. $4: 663-670,1978$.

6) Mossman, K.L., J.D. Chencharick, A.C. Scheer, W.P. Walker, R.D. Ornitz, C.C. Rogers and R.I. Henkin : Radiation-induced changes in gustatory function. Comparison of effects of neutron and photon irradiation. $5: 521-528,1979$.

7 ）冨田 寛・富山紘彦・岸 拓三：味蕾の病理。神経進歩 $25: 344-353,1981$.

8) Conger, A.D. and Wells, M.A. : Radiation and aging effect on taste structure and function. Radiat. Res. $37: 31-49,1969$.

9）太田 正：口腔組織に及ぼす放射線の影響。九州歯会誌 $27: 200-220,1973$.

10) Schatzman, A.R. and Mossman, K.L. : Radiation effects on bovine taste bud membranes. Radiat. Res. $92: 353-358,1982$. 
11) Ghoneum, M.M., Ijiri, K., Hamed, M.S. Gabr, O.M. and Egami, N. : Effects of Gamma rays on the taste buds of embryo and adults of the fish, Oryzias. J. Radiat. Res. $24: 278-283$, 1983.

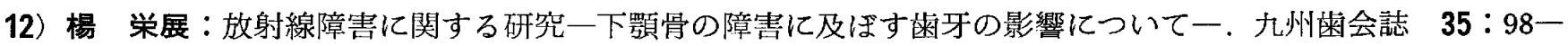
122,1981 .

13) Karnovsky, M.J. : A formaldehyde-glutaraldehyde fixative of high osmolality for use in electron microscopy. J. Cell Biol. $27:$ 137-138A, 1965.

14) Brouwer, J.N. and Wiersma, A : Location of taste buds in intact taste papillae by a selective staining method. Histochemistry. $58: 145-151,1978$.

15) Coutard, H. : Roentgen therapy of epitheliomas of the tonsillar region, hypopharynx and larynx, from 1920 to 1926. Am. J. Roentgenol. $28: 313-331,1932$.

16) Rubin, P. and Casarett, G.W. : Clinical radiation pathology. Vol. 1, Saunders, Philadelphia, 1968, 120-152.

17）代田源六郎：ラジウム放射線に対する口腔粘膜の態度について (実験的研究)。京府医大誌 $6: 1119$ 一 $1133,1932$.

18）大竹正敏：X線照射が歯牙および口腔諸組織に及ぼす影響。日本口腔科学会誌 $7: 74-89,1958$.

19) Dale, P.P. : The effect of X-ray irradiation on the rat incisor. J. Dent. Res. 32:117-125, 1953.

20) Vos, O., Wensinck, F. and Van Bekkum, D.W. : Lesion of the tongue in irradiated mice. Radiat. Res. 10:339-346, 1959.

21) Shapiro, M., Brat, V. and Ershoff, B.H. : Periodontal changes following multiple sublethal doses of X-irradiation in the mouse (Abstract). J. Dent.Res. 39:668, 1960.

22) Goepp, R.A. and Fitch, F.W. : Radiation effects on oral epithelium in mice. J. Dent. Res. 48 (Suppl.) : 641-645, 1969.

23) Miller, M.E., G.C., Christensen and H.E. Evans: Anatomy of the dog. Saunders, Philadelphia, $1967,654-656,868-875$.

24) Adam, W.S., Calhoun, M.L., Smith, E.M. and Stinson, A.W. : Microscopic anatomy of the dog. Charles C. Thomas Pub., Springfield, 1970, 102-113.

25）藤 英俊・大森忠雄・三好作一郎：走査電顕によるカイイヌ舌乳頭の 観察. 九州柬会誌 $36: 468-475$, 1982 .

26）北村勝也：味蕾の変性並びに再生に関する神経組織学的研究. 九州霜会誌 $18 ： 96-135,1965$.

27) Fujimoto, S. and R.G. Murray. : Fine structure of degeneration and regeneration in denervated rabbit vallate taste buds. Anat. Rec. $168: 393-414,1970$.

28）池田政信：乳歯列期口腔組織の放射線障害に関する実験的研究.九州歯会誌 $39: 415-438,1985$.

29）久芳陽一：幼若期口腔組織の放射線障害に関する実験的研究．九州柬会誌 $40: 70-90,1986$.

30）河井 新：幼若期下顎骨の放射線障害に関する実験的研究．九州雨会誌 $40 ： 119-143,1986$.

31）永山武彦：放射線照射の乳蒾柬㵦および㐘根膜に及ぼす影響に関する実験的研究.九州歯会誌 $40: 555 一$ $580,1986$.

32）瀬尾令士：乳歯列期下顎骨の放射線障害に関する実験的研究. $40: 761-786,1986$.

33）生駒文俊：放射線照射後の家鬼歯根膜の微細血管の変化に関する研究. 歯学 $61 ： 323-340,1973$. 